\title{
Use of a Tumor Bed Boost in the Radiotherapy after Oncoplastic Breast Conserving Surgery
}

\author{
Liviu Stoleru' ${ }^{1}$ Smaranda Stoleru ${ }^{2 *}$, Bogdan Gaspar ${ }^{2,3}$, Aniela Nodiți̦ ${ }^{2,4}$ and Alexandru Blidaru ${ }^{2,4}$ \\ 'Department of Radiotherapy, Neolife Medical Center, Bucharest, Romania \\ 2"Carol Davila" University of Medicine and Pharmacy, Bucharest, Romania \\ ${ }^{3}$ Clinical Emergency Hospital, Department of Surgery, Bucharest, Romania \\ ${ }^{4}$ Department of Surgery, "Prof. Dr. Alexandru Trestioreanu" Institute of Oncology, Bucharest, Romania
}

*Corresponding author: Smaranda Stoleru, MD, PhD

"Carol Davila" University of Medicine and Pharmacy, Department of

Pharmacology and Pharmacotherapy Bucharest, Romania

E-mail: smaranda.stoleru@umfcd.ro

\section{Rezumat}

Utilizarea unei doze suplimentare de iradiere la nivelul patului tumoral după intervenția chirurgicală conservatoare oncoplastică a sânului

Scopul studiului: Utilizarea unei doze suplimentare de iradiere la nivelul patului tumoral (boost) adaugată la cea provenită din iradierea sânului întreg după chirurgia oncoplastică a sânului, poate fi dificil de realizat din cauza deplasărilor masive ale țesuturilor. Scopul studiului nostru este de a prezenta date relevante de radioterapie (RT) referitoare la utilizarea boost-ului la paciente operate prin tehnica oncoplastică care au efectuat RT adjuvantă la Neolife Medical Center Bucureşti.

Materiale şi metode: Au fost incluse în studiu 12 paciente tratate cu radioterapie $\mathrm{cu}$ intensitate modulată (IMRT), utilizând scheme de fractionare convențională sau hipofracționare, între 10/2018 şi 12/2020. Imaginile CT pre- şi postoperatorii şi agrafele chirurgicale, atunci când au fost disponibile, au fost folosite pentru localizarea patului tumoral şi definirea volumului țintă pentru boost. Rezultate: Unul sau mai mulți factori de risc pentru recidiva locală (vârsta sub 51 ani, tumori de grad înalt, asocierea cu carcinom ductal in situ) au fost prezenți la 10 paciente. Boost-ul a fost administrat la 3 paciente.

Concluzii:Localizarea patului tumoral pentru administrarea boostului este dificilă fără un marcaj adecvat. Agrafele chirurgicale şi comunicarea dintre chirurg şi radioterapeut sunt esențiale pentru succesul tratamentului.

Cuvinte cheie: cancer mamar, chirurgie oncoplastică, radioterapie 


\begin{abstract}
Aim of the study: Use of a radiotherapy (RT) tumor bed boost in addition to whole breast irradiation (WBI) after oncoplastic breast conserving surgery (OBCS) can be very challenging due to the massive tissue displacements. The aim of our study is to present relevant RT data regarding the use of a boost $\mathrm{RT}$ in patients who underwent OBCS and received adjuvant $\mathrm{RT}$ at Neolife Medical Center Bucharest.

Materials and Methods:12 patients treated with intensity modulated radiotherapy (IMRT), after OBCS, using conventional or hypofractionated schedules, between 10/2018 and 12/2020 were included in the study. Pre- and postoperative CT images and surgical clips when available were used for tumor bed (TB) localization and definition of the boost volume.

Results: One or more risk factors associated with local recurrence (age under 51 years, high grade tumors, associated ductal carcinoma in situ) were present in 10 patients. Boost RT was delivered in 3 patients.

Conclusions: TB localization for the boost RT is difficult without an appropriate marking. Surgical clips and communication between the surgeon and the radiation oncologist are essential for treatment success.
\end{abstract}

Key words: breast cancer, oncoplastic surgery, radiotherapy

\section{Background}

Breast conserving therapy consisting of breast conserving surgery (BCS) and postoperative whole breast irradiation (WBI) is an alternative to mastectomy for the treatment of early breast cancer in terms of local control and survival $(1,2,3)$.

Unfortunately, the excision of the breast tumor leaves a local deformity in $20-30 \%$ of cases, with major long-term consequences on cosmesis and quality of life of the patient (4).

Oncoplastic breast conserving surgery (OBCS) is a combination of breast conserving resection and plastic surgical reconstruction aiming to achieve optimal oncologic and esthetic outcomes, "a third pathway between standard BCS and mastectomy" (5).

Indications for OBCS include clinical scenarios when adequate local excision results in significant deformity such as:

1. resection of more than $20 \%$ of breast volume;

2. central, medial and lower quadrants resection;

3. axillary dissection via large lateral quadrant resections;

4. cosmetic considerations - macromastia, significant ptosis or breast asymmetry (6).

According to the classification of Clough et al, there are 2 levels in the oncoplastic approach which are based on the resected breast volume:

- level 1 procedure requiring less than $20 \%$ volume resection;

- level 2 requiring more than 20\% (5).

Level 2 procedures are more complex and described as 2 groups of procedures: volume replacement (VR) and volume displacement (VD).

In VR techniques, the glandular gap is filled with either autologous tissue from another site, or with a breast implant.

VD procedures use mammoplasty techniques to fill the glandular defect. Breast and fatty tissue are displaced and relocated resulting in a redistribution and equal reduction of breast volume as a whole and not just at the tumor area (7).

The role of radiotherapy (RT) after BCS has been clearly demonstrated.

In a meta-analysis of individual patient data for 10801 women in 17 randomized trials, RT after BCS, halves the rate of disease recurrence and reduce cancer 
mortality by a sixth (8). The benefit of the tumor bed boost (TBB) in addition to WBI in terms of local control is supported by landmark randomized trials $(9,10)$ and systematic reviews and meta-analysis (11). The relative benefit of the boost was independent of age, but the absolute gain was largest in patients younger than 51 years (9) and its use is recommended by current clinical guidelines $(12,13)$.

However, the cosmetic results and fibrosis were worse after TBB with larger boost volumes associated with diminished cosmesis and increased fibrosis (14-17).

These are very important issues, because younger women with large tumors have an increased risk of local recurrence and this group of patients are more frequently undergoing OBCS. Therefore, a TBB would be of greater benefit to them. Conversely, administration of the TBB may jeopardize the esthetic outcome which is a main goal of the OBCS (18-20).

WBI, with or without nodal irradiation after the oncoplastic procedure, is identical with that performed after standard BCS. In contrast, the localization of the tumor bed for the boost in this setting is difficult if not impossible because OBCS frequently results in extensive breast tissue rearrangements, relocating the TB (21).
However, the boost volume needs to be clearly defined, in order to decrease the risk of recurrence and complications. Irradiation of a small, but poorly localized boost volume, may result in geographic miss of the TB, whereases irradiation of a large volume to avoid a geographic miss may lead to a poor cosmetic outcome (22).

A criticism of the oncoplastic surgery studies was that the details regarding the use of a boost and the tumor bed marking were, most frequently, not reported but they are necessary in an effort to improve the current RT techniques after $\operatorname{OBCS}(20,23)$.

The aim of our study is to provide specific $\mathrm{RT}$ data regarding the use of a boost in addition to WBI in patients who underwent VD-OBCS.

\section{Materials and Methods}

12 patients who underwent VD-OBCS and were treated in the radiotherapy department of Neolife Medical Center, Bucharest, between 10/2018-12/2020, were included in the study.

In terms of surgical technique there were 5 patients with breast conserving treatment using the "round-block" oncoplastic technique (Fig. 1), 6 patients with therapeutic mammoplasty using "wise-pattern" technique (Fig. 2) from which 1 patient with therapeutic

Figure 1. Breast conserving treatment using „round-block" oncoplastic technique
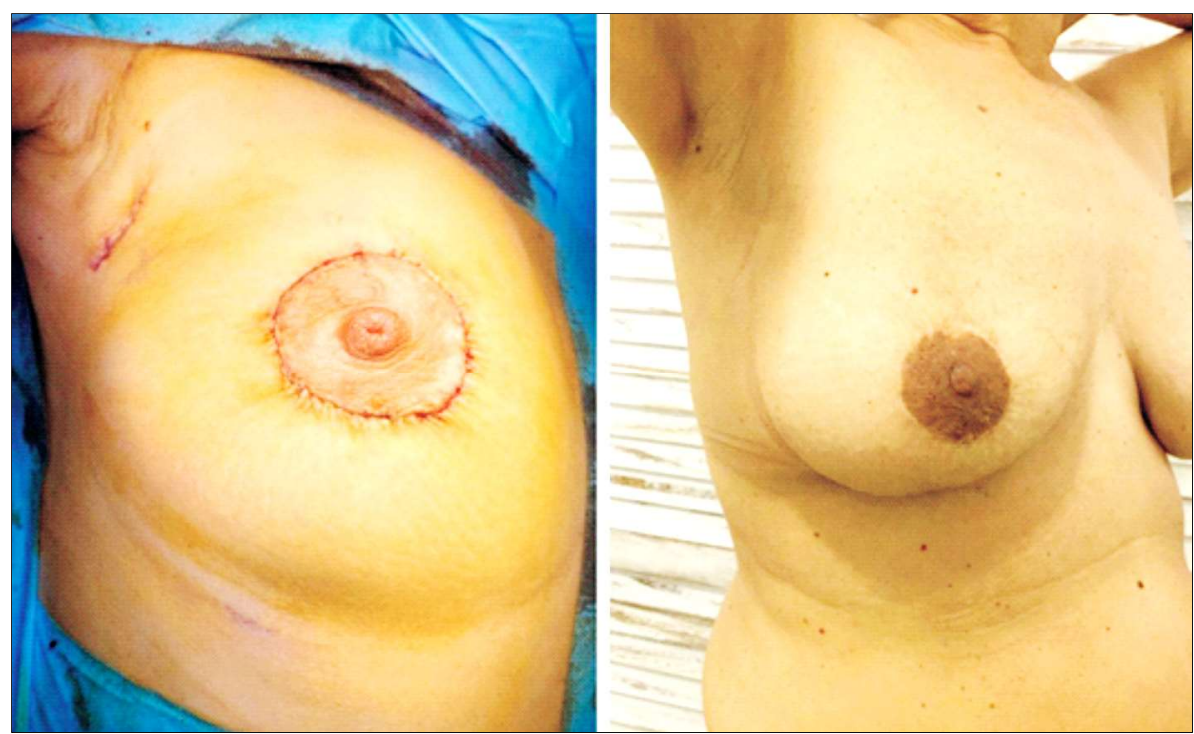
Figure 2. Therapeutic mammoplasty using "wise-pattern" technique
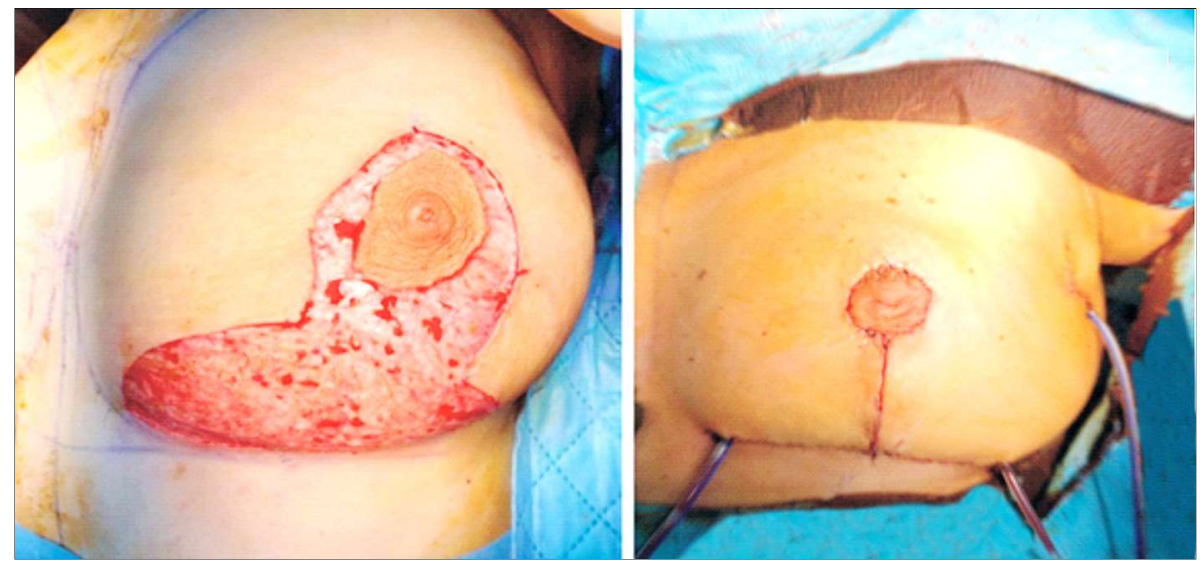

Figure 3. Therapeutic

mammoplasty and reduction mammoplasty using "wise-pattern" technique

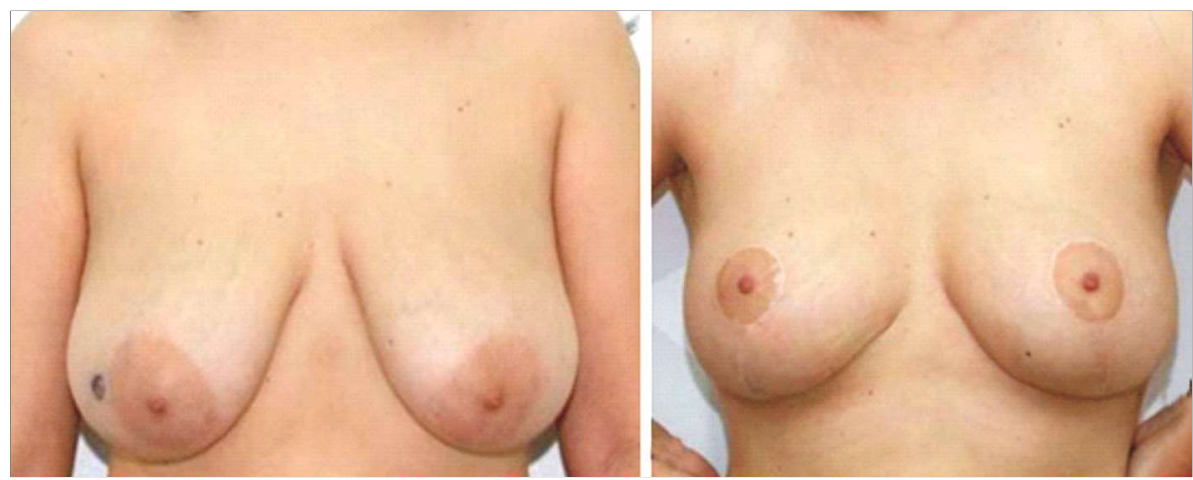

mammoplasty and contralateral reduction mammoplasty (Fig. 3) and 1 patient with breast conserving treatment using a "trian" gular" oncoplastic technique (Fig. 4).

Patients and RT data have been retrieved from medical records an treatment planning system, respectively. Each patient underwent CT-based simulation to obtain 3D anatomy data for RT planning.

Simulation has been performed in the treatment position with the patient lying supine on a breast board with both arms above the head.

Images were transferred from $\mathrm{CT}$ to the treatment planning system (Varian Eclipse). Target volumes delineations for the WBI, TBB

Figure 4. Breast conserving treatment using "triangular" oncoplastic technique
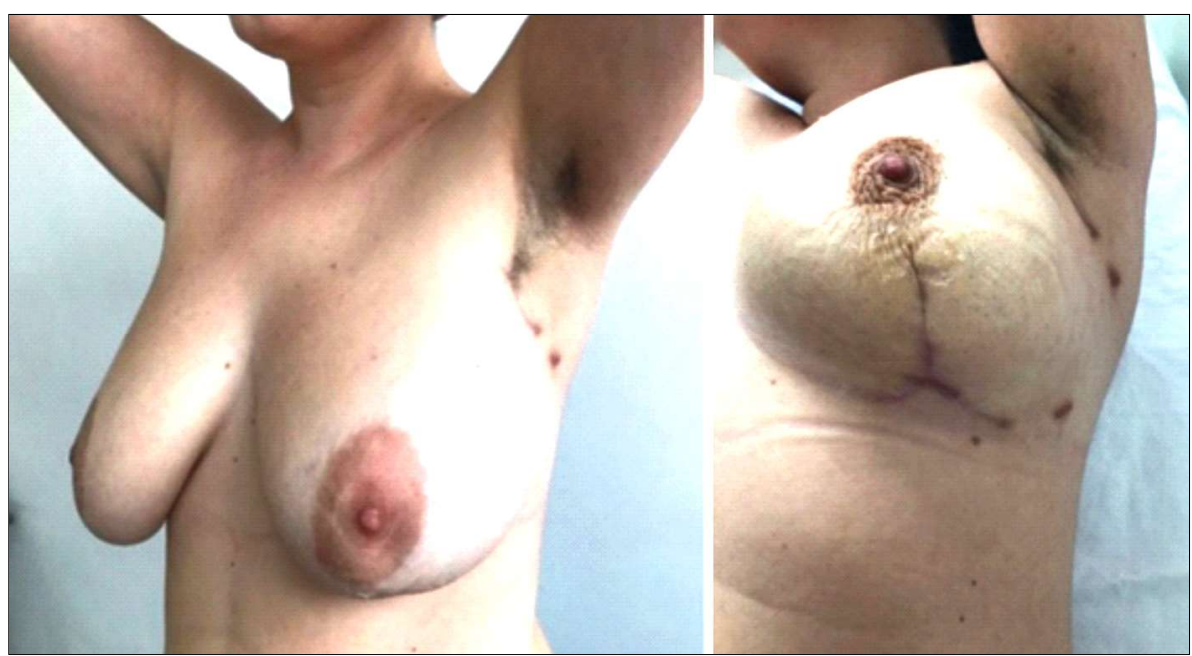
and nodal irradiation, as well as the organs at risk, were performed by the radiation oncologist according to ESTRO contouring guidelines (24).

Preoperative diagnostic CT scan images for the location of the primary tumor and postoperative changes in the simulation CT scan in combination with surgical clips, where available, have been used to assist for TBB delineation.

All patients were treated with $6 \mathrm{MV}$ energy photons from a linear accelerator, using intensity modulated radiotherapy (IMRT) sliding window technique 5 day per week, from Monday to Friday.

Regarding the dose-fractionating schedule, either a conventional schedule (total dose of $50 \mathrm{~Gy}$ in 25 daily fractions of $2 \mathrm{~Gy}$ ) or a hypofractionated one (total dose of 40-42.56Gy in 15 -16 fractions of $2.66-2.67 \mathrm{~Gy})$ were used for the WBI.

Conventional fractionation has been used for nodal and sequential TBB irradiation.

The accuracy of patient positioning on the treatment couch before each RT session has been verified by daily portal imaging, according to an institutional protocol.

\section{Results}

Patient characteristics are presented in Table 1.
The mean age of our group was 51.4 years (range 38-66); 7 patients (58\%) were younger than 51 years.

Four patients were in stage I, 6 in stage II and 2 in stage IIIA. All patients were estrogen receptor positive, with 3 of them being also positives for the epidermal growth factor receptor 2 (HER 2 positives).

Five patients $(41.6 \%)$ have poorly differentiated tumors (G3) and 5 have associated ductal carcinoma in situ (DCIS) to the invasive component; none have positive margins or lymphovascular invasion on the postoperative pathology specimen. Internal inner quadrant was the most frequent location for the primary tumor (7 patients $58 \%$ cases).

Chemotherapy has been administered in 4 patients (33\% of cases) - 2 in a neo adjuvant and 2 in an adjuvant setting.

$\mathrm{RT}$ characteristics are presented in Table 2.

All patients received WBI, with a hypofractionated schedule in 8 patients $(66.6 \%)$, and a conventional one in 4 .

A sequential TBB in addition to the WBI was administered in 3 patients $(25 \%)$ and 3 patients received nodal irradiation.

The mean time between surgery and RT was 73 days (range 42-175) when adjuvant chemotherapy was not administered and 219 days (range 203-235) with adjuvant chemotherapy.

Table 1. Patients characteristics

\begin{tabular}{|c|c|c|c|c|c|c|c|c|c|}
\hline $\begin{array}{l}\text { Patient } \\
\text { number }\end{array}$ & Age & $\begin{array}{l}\text { Tumor } \\
\text { staging }\end{array}$ & Receptor status & $\begin{array}{l}\text { Tumor } \\
\text { grade }\end{array}$ & $\begin{array}{l}\text { Associated } \\
\text { DCIS }\end{array}$ & $\begin{array}{l}\text { Positive } \\
\text { margins }\end{array}$ & $\begin{array}{c}\text { Lymphovascular } \\
\text { invasion }\end{array}$ & $\begin{array}{l}\text { Location } \\
\text { (quadrant) }\end{array}$ & $\begin{array}{l}\text { Type of } \\
\text { surgery }\end{array}$ \\
\hline 1 & 46 & I & $\mathrm{ER}+, \mathrm{PR}+, \mathrm{HER} 2-$ & G2 & Yes & No & No & UI & wise-pattern \\
\hline 2 & 49 & I & $\mathrm{ER}+, \mathrm{PR}+, \mathrm{HER} 2-$ & G2 & No & No & No & Cent. & round-block \\
\hline 3 & 47 & $\| A$ & $\mathrm{ER}+, \mathrm{PR}+, \mathrm{HER} 2-$ & G2 & No & No & No & $\mathrm{LI}$ & triangular \\
\hline 4 & 52 & IIB & ER+, PR+, HER2- & G2 & Yes & No & No & UO & wise-pattern \\
\hline 5 & 49 & $\mathrm{I}$ & ER+, PR+, HER2- & G2 & Yes & No & No & UI & wise-pattern \\
\hline 6 & 38 & $\| \mathrm{A}$ & ER,+ PR-, HER2 3+ & G3 & Yes & No & No & UI & wise-pattern \\
\hline 7 & 48 & $\| A$ & $\mathrm{ER}+, \mathrm{PR}+, \mathrm{HER} 2-$ & G2 & No & No & No & $\mathrm{UI}$ & wise-pattern \\
\hline 8 & 57 & IIIA & $\mathrm{ER}+, \mathrm{PR}+, \mathrm{HER} 2-$ & G3 & Yes & No & No & UO & round-block \\
\hline$\overline{9}$ & 66 & $\| \mathrm{A}$ & $\mathrm{ER}+, \mathrm{PR}+, \mathrm{HER} 23+$ & G3 & No & No & No & $\mathrm{UI}$ & round-block \\
\hline 10 & 59 & I & $\mathrm{ER}+, \mathrm{PR}+, \mathrm{HER} 2-$ & G1 & No & No & No & $\mathrm{UI}$ & round-block \\
\hline 11 & 58 & IIB & $\mathrm{ER}+, \mathrm{PR}+, \mathrm{HER} 2-$ & G3 & No & No & No & UO & round-block \\
\hline 12 & 48 & IIIA & $\mathrm{ER}+, \mathrm{PR}+, \mathrm{HER} 23+$ & G3 & No & No & No & UI & wise-pattern \\
\hline
\end{tabular}

ER - estrogen receptor; PR - progesterone receptor; HER2 - epidermal growth factor receptor 2 UI - upper inner; UO - upper outer; cent - central; LI - lower inner

G1 - low grade; G2 - intermediate grade; G3 - high grade 
Table 2. Radiotherapy characteristics

\begin{tabular}{|c|c|c|c|c|c|c|}
\hline $\begin{array}{l}\text { Patient } \\
\text { number }\end{array}$ & WBRT fractionation & $\begin{array}{c}\text { Nodal RT } \\
\text { - fractionation }\end{array}$ & $\begin{array}{c}\text { TB boost RT } \\
\text { - fractionation }\end{array}$ & $\begin{array}{l}\text { Clips / } \\
\text { number }\end{array}$ & Chemotherapy & $\begin{array}{l}\text { Surgery to } \\
\text { RT interval }\end{array}$ \\
\hline 1 & $40 \mathrm{~Gy} / 15$ fractions & No & Yes - 10Gy/ 5 fractions & Yes / 1 & No & 60 days \\
\hline 2 & $42.56 \mathrm{~Gy} / 16$ fractions & No & No & No & No & 57 days \\
\hline 3 & 42.56 Gy/16 fractions & No & No & No & No & 175 days \\
\hline 4 & 50 Gy/25 fractions & No & No & No & Adjuvant & 203 days \\
\hline 5 & $42.56 \mathrm{~Gy} / 16$ fractions & No & No & No & No & 81 days \\
\hline 6 & 42.56 Gy/16 fractions & No & No & No & Neoadjuvant & 63 days \\
\hline 7 & 42.56 Gy/16 fractions & No & No & No & Neoadjuvant & 48 days \\
\hline 8 & $50 \mathrm{~Gy} / 25$ fractions & Yes - 50 Gy/ 25 fractions & No & No & Adjuvant & 235 days \\
\hline 9 & 40 Gy/15 fractions & No & No & No & Neoadjuvant & 42 days \\
\hline 10 & $40 \mathrm{~Gy} / 15$ fractions & No & No & No & No & 48 days \\
\hline 11 & $50 \mathrm{~Gy} / 25$ fractions & Yes - 50 Gy/ 25 fractions & Yes - 10Gy/ 5 fractions & No & Neoadjuvant & 76 days \\
\hline 12 & 50 Gy/25 fractions & Yes - 50 Gy/ 25 fractions & Yes - 10Gy/ 5 fractions & No & Neoadjuvant & 80 days \\
\hline
\end{tabular}

WBRT - whole breast radiotherapy; TB - tumor bed

\section{Discussions}

The most challenging issue for the radiation oncologist is the localization of the tumor bed, which can be relocated after oncoplastic surgery, due to extensive tissue displacements that frequently occur during the procedure.

Standard methods of the tumor bed localization are often useless. Postoperative scar is useful for localization when is placed over the tumor site, but oncoplastic incisions, particularly inverted $\mathrm{T}$ incisions, may have no relationship to the real TB location. Visualization of a seroma on the postoperative planning CT scan, maybe a result of the plastic surgery reconstruction, rather than the defect corresponding to the tumor bed.

Moreover, reposition of the nipple areola complex (NAC), changes what tissue is located in which quadrant, when quadrants are defined relative to NAC (22).

In the study of Alco et al, tumor bed shifts out of the primary quadrant with mean shifts of approximately $1 \mathrm{~cm}$ in all directions, were reported in $36.4 \%$ of patients, while preoperative and postoperative tumor bed volumes were fully superposed in only 5 of the 22 cases (25).

Tumor bed was often large, irregularly shaped and/or split into 2 or 3 regions within the breast in Pezner's study (22), while Kirova et al showed that most of the breast and particularly the tumor bed cavity undergoes significant 3D deformation during the oncoplastic reconstruction (26).

Surgical clips in combination with CT simulation images, have been shown to increase accuracy and reduce interobserver variability in tumor bed delineation after conventional BCS (27-31). Although, surgical clips in conjunction with $\mathrm{CT}$ simulation images have been demonstrated to increase accuracy and reduce interobserver variability in TB localization, practice of clips usage is not a routine in patients undergoing BCS.

In a retrospective UK study, Kirwan et al reported that surgeons compliance with clips usage, despite recommended in national guidelines, was proportional to research activity related to IMRT trials (32).

The utility of clips in tumor bed delineation after OBCS has also been documented in three studies, but the optimal number of clips recommended was different $(22,33,34)$.

In a recent survey on radiation practice among US radiation oncologist conducted by Thomas et al, only $33.1 \%$ of responding radiation oncologist indicated that the oncoplastic surgeons regularly place clips, while $33.8 \%$ indicated that clips are occasionally placed and $28.6 \%$ stated clips are not routinely placed.

Additionally, $38.7 \%$ of respondents, routinely deliver a boost for patients undergoing breast reduction only if clips have been placed in the tumor cavity, while $34.6 \%$ indicated that a boost 
Table 3. Recommended number of clips for tumor bed localization in oncoplastic surgery studies

\begin{tabular}{lcc}
\hline Author & Number of patients & $\begin{array}{c}\text { Number of clips } \\
\text { recommended }\end{array}$ \\
\hline Furet et al (33) & 18 & $\geq 3$ \\
\hline Pezner et al (22) & 11 & $6-10$ \\
\hline Riina et al (34) & 39 & 4 \\
\hline
\end{tabular}

is used regardless of clip placement (35).

The optimal number of clips to be placed for effectively marking the tumor bed was different among OBCS studies (Table 3).

According to a very recently published consensus statement on tumor bed localization for RT after OBCS, the optimal number of clips is at least 4, with one clip placed on each of the cavity side walls (medial, lateral, superior, inferior).

Additionally, 1-4 clips can be placed on the posterior margin, which might or might not be the chest wall (36).

In our study, only 1 patient has a single one clip placed for tumor bed localization.

We used a $2 \mathrm{~cm}$ clip margin for the TBB clinical target volume (CTV) (Fig. 5).

This margin has been suggested to be appropriate to minimize geographic miss and for sparing of the normal surrounding tissues (37). However, according to Kirby et al (38), CTV delineation of the TBB based on 0 or 1 implanted markers is not recommended as large additional margins are required to account for uncertainty over true tumor bed location.

Only 3 patients received a TBB in addition to WBI in our study. In one patient, placement of the clip was used to guide the tumor bed localization and delineate the boost CTV, whereas in the other 2 , postoperative changes in breast tissue density on the simulation CT scan, in combination with preoperative CT images for the primary tumor location, were used for CTV boost delineation.

The American Society for Radiation Oncology (ASTRO) and the National Comprehensive Cancer Network (NCCN) recommend boost $\mathrm{RT}$ in patients considered at high risk for local recurrence (age under 50 years, high tumor grade and close or positive margins) $(12,13)$.

Additionally, the presence of DCIS adjacent to the invasive component of the tumor has also been associated with an increased recurrence rate at 20 years ( $18 \%$ vs $9 \%, p<0.01)$ in the EORTC boost vs no boost trial. (39)

Considering these risk factors for local recurrence, TBB should have been administered in 10 cases in our study.

The reason for not delivering a boost in 7 patients was that the TB for boost volume
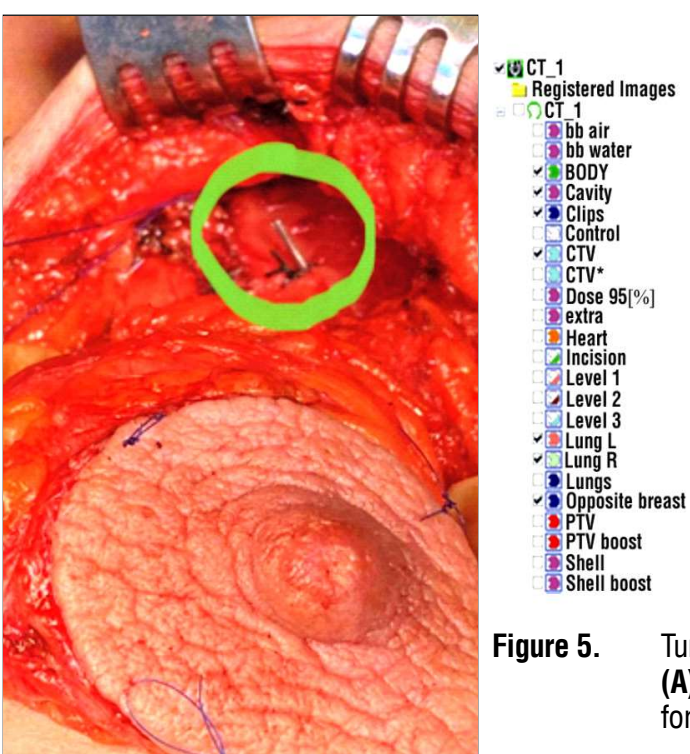

Figure 5. Tumor bed localization for boost radiotherapy

(A) Surgical clip placed for marking the tumoral bed. (B) clinical target volume for the tumoral bed boost 
delineation could not precisely be localized based only on the preoperative CT and postoperative changes on the simulation CT scan.

Kirova et al stated that the definition of the boost volume after OBCS is impossible without detailed report of the surgical procedure, use of clips in the tumor bed volume and, if possible, a preoperative CT scan in treatment position (26).

Difficulties in TB localization is a common cause of not delivering the boost RT in the context of oncoplastic surgery.

In the study of Maguire et al, 79 patients included in the study received WBI after the oncoplastic surgery, but none had a TBB since no tumor bed was discernible to target (40).

Due to inability to accurately delineate the postsurgical tumor bed, the lumpectomy cavity was contoured in $66 \%$ women and only $16 \%$ of 38 women received a cavity boost in the study of Arya et al (41).

In the retrospective study of Borm et al on 965 patients who underwent BCS between $01 / 2005$ and $12 / 2005$, with 288 patients undergoing OBCS, an additional boost was administered in $93.3 \%$ of cases, but boost irradiation was more frequently omitted in the oncoplastic group (9\% vs $5.8 \%, \mathrm{p}=0.06)(42)$.

However, it is important to be aware that use of surgical clips has several limitations.

Each clip marks a single point within the surgical bed, requiring radiation oncologist to interpolate the borders of the cavity, leading to potential inaccuracy in target delineation (43).

Displacement of the clips during treatment may result in geographic miss (44).

Surgical clips assist in defining the borders of the excised tissue but do not inform on the distance of the tumor from the border of the resected tissue which can be variable (45).

Moreover, clips may be placed by surgeons for hemostatic purposes. Contouring of such clips may result in an overestimation of the tumor bed (22).

Therefore, TBB volume definition, based only on surgical clips, may be also prone to inaccuracies and to overcome this inconvenient, a close cooperation between the surgeon and the radiation oncologist is needed $(20,23,26,46)$.

A preoperative multidisciplinary evaluation is crucial in order to identify the necessity of and the target for a boost in patients where OBCS is anticipated (47).

After the oncoplastic procedure, the surgeon should provide to the radiation oncologist detailed information on how the TB has been displaced from the original position and how it has been marked to facilitate boost volume delineation (20).

The value of a boost in an individual patient should carefully be considered in terms of estimated benefit in local control vs possible impairment of the esthetic outcome. Maybe OBCS may not be the ideal solution for patients with multiple risk factors, who may derive the most benefit from a TBB. On the other hand, a TBB may be omitted in patients desiring OBCS who have a low risk for local recurrence (eg age under 60-70 years, hormone receptors positive tumors taking adjuvant endocrine therapy, low or intermediate grade) $(12,48)$.

Although, current data in the literature support the need to consider a boost in most women undergoing BCS, there are questions regarding the magnitude and the clinical relevance of its benefit given, the updated surgical procedures and systemic therapy in the modern era $(11,21,36,47)$. Furthermore, a boost in addition to WBI was not shown to improve local control at a median follow-up of 11 years in Her2 positive patients treated with BCS, WBI and traztuzumab; when analyzing patients by age, patients $<40$ years of age had a higher risk for local recurrence, but this was not lowered by the addition of a boost (49).

It might be possible for patients who undergo OBCS with negative pathologic margins to be optimally treated without a local boost $(21,36)$.

Defining precise selection criteria for the use of the TBB, a good communication between surgeons and radiation oncologists as how to target the tumor bed and offering the necessary information regarding the benefit in local control and the possible negative impact 
of the boost on esthetical outcome to the patient, are key issues for the success of oncoplastic procedures.

Our study has a quite limited number of patients and a short follow-up. Therefore we cannot draw any conclusion regarding the local control or esthetic outcome, but these patients will be monitored and represent a basis for future comparisons as our surgical team has begun to place clips for marking the TB for oncoplastic procedures, on a routine basis, from January 2021.

\section{Conclusions}

The results of this study show the importance of tumor bed marking in order to perform a cancer treatment as complete as possible.

In Romania, more and more oncoplastic surgical interventions for breast cancer have started to be performed, but the location of the tumor bed has not yet entered the current practice.

TB localization for boost RT after OBCS is challenging and requires appropriate marking with clips and a close cooperation between the surgeon and the radiation oncologist. The real value provided by the boost after oncoplastic procedures in the era of modern systemic treatments should be clarified in future studies.

\section{Conflict of interests and source of funding}

The authors declare no conflicts of interests. No grants or sponsorships were provided for the present research.

\section{Ethics Approval}

All procedures performed involving human participants were in accordance with the ethical standards of the 1964 Helsinki Declaration and its later amendments.

\section{References}

1. van Dongen JA, Voogd AC, Fentiman IS, Legrand C, Sylvester RJ, Tong D, et al. Long-term results of a randomized trial comparing breast-conserving therapy with mastectomy: European Organization for Research and Treatment of Cancer 10801 trial. J Natl Cancer Inst. 2000;92(14):1143-50.

2. Veronesi U, Cascinelli N, Mariani L, Greco M, Saccozzi R, Luini A, et al. Twenty-year follow-up of a randomized study comparing breast-conserving surgery with radical mastectomy for early breast cancer. N Engl J Med. 2002;347(16):1227-32.

3. Fisher B, Anderson S, Bryant J, Margolese RG, Deutsch M, Fisher ER, et al. Twenty-year follow-up of a randomized trial comparing total mastectomy, lumpectomy, and lumpectomy plus irradiation for the treatment of invasive breast cancer. N Engl J Med. 2002; 347(16):1233-41.

4. Clough KB, Cuminet J, Fitoussi A, Nos C, Mosseri V. Cosmetic sequelae after conservative treatment for breast cancer: classification and results of surgical correction. Ann Plast Surg. 1998;41(5):471-81.

5. Clough KB, Kaufman GJ, Nos C, Buccimazza I, Sarfati IM. Improving breast cancer surgery: a classification and quadrant per quadrant atlas for oncoplastic surgery. Ann Surg Oncol. 2010;17(5):1375-91.

6. Strach MC, Prasanna T, Kirova YM, Alran S, O'Toole S, Beith JM, et al. Optimise not compromise: The importance of a multidisciplinary breast cancer patient pathway in the era of oncoplastic and reconstructive surgery. Crit Rev Oncol Hematol. 2019;134:10-21. Epub 2018 Nov 30.

7. Habibi M, Broderick KP, Sebai ME, Jacobs LK. Oncoplastic Breast Reconstruction: Should All Patients be Considered? Surg Oncol Clin N Am. 2018:27(1):167-180.

8. Early Breast Cancer Trialists' Collaborative Group (EBCTCG); Darby S, McGale P, Correa C, Taylor C, Arriagada R, Clarke M, et al. Effect of radiotherapy after breast-conserving surgery on 10-year recurrence and 15-year breast cancer death: meta-analysis of individual patient data for 10801 women in 17 randomised trials. Lancet. 2011;378(9804):1707-16

9. Bartelink H, Horiot JC, Poortmans PM, Struikmans H, Van den Bogaert W, Fourquet $\mathrm{A}$, et al. Impact of a higher radiation dose on local control and survival in breast-conserving therapy of early breast cancer: 10-year results of the randomized boost versus no boost EORTC 22881-10882 trial. J Clin Oncol. 2007;25(22):3259-65

10. Romestaing $P$, Lehingue $Y$, Carrie $C$, Coquard R, Montbarbon X, Ardiet JM, et al. Role of a 10-Gy boost in the conservative treatment of early breast cancer: results of a randomized clinical trial in Lyon, France. J Clin Oncol. 1997:15(3):963-8.

11. Kindts I, Laenen A, Depuydt T, Weltens C. Tumour bed boost radiotherapy for women after breast-conserving surgery. Cochrane Database Syst Rev. 2017; 11(11):CD011987.

12. Smith BD, Bellon JR, Blitzblau R, Freedman G, Haftty B, Hahn C, et al. Radiation therapy for the whole breast: Executive summary of an American Society for Radiation Oncology (ASTRO) evidence-based guideline. Pract Radiat Oncol. 2018;8(3):145-152.

13. NCCN Clinical Practice in Oncology (NCCN Guidelines). Breast cancer. Version 1.2021 - January 15, 2021

14. Collette S, Collette L, Budiharto T, Horiot JC, Poortmans PM, Struikmans H, et al; EORTC Radiation Oncology Group. Predictors of the risk of fibrosis at 10 years after breast conserving therapy for early breast cancer: a study based on the EORTC Trial 22881-10882 'boost versus no boost'. Eur J Cancer. 2008:44(17):2587-99. Erratum in: Eur J Cancer. 2009:45(11):2061.

15. Vrieling C, Collette L, Fourquet A, Hoogenraad WJ, Horiot JH, Jager JJ, et al. The influence of patient, tumor and treatment factors on the cosmetic results after breast-conserving therapy in the EORTC 'boost vs. no boost' trial. EORTC Radiotherapy and Breast Cancer Cooperative Groups. Radiother Oncol. 2000;55(3):219-32.

16. Immink JM, Putter $\mathrm{H}$, Bartelink $\mathrm{H}$, Cardoso JS, Cardoso MJ, van der HulstVijgen MHV, et al. Long-term cosmetic changes after breast-conserving treatment of patients with stage $1-$ II breast cancer and included in the EORTC 'boost versus no boost' trial. Ann Oncol. 2012:23(10):2591-2598.

17. Brouwers PJAM, van Werkhoven E, Bartelink H, Fourquet A, Lemanski C, van Loon J, et al. Predictors for poor cosmetic outcome in patients with early stage breast cancer treated with breast conserving therapy: Results of the Young boost trial. Radiother Oncol. 2018;128(3):434-441.

18. Kronowitz SJ, Hunt KK, Kuerer HM, Strom EA, Buchholz TA, Ensor JE, et al. Practical guidelines for repair of partial mastectomy defects using the breast reduction technique in patients undergoing breast conservation therapy. Plast Reconstr Surg. 2007;120(7):1755-1768. 
19. Rietjens M, Urban CA, Rey PC, Mazzarol G, Maisonneuve P, Garusi C, et al. Long-term oncological results of breast conservative treatment with oncoplastic surgery. Breast. 2007;16(4):387-95.

20. Yoon JJ, Green WR, Kim S, Kearney T, Haffty BG, Eladoumikdachi F, Goyal S Oncoplastic breast surgery in the setting of breast-conserving therapy: A systematic review. Adv Radiat Oncol. 2016; 1(4):205-215.

21. Pezner RD. The oncoplastic breast surgery challenge to the local radiation boost. Int J Radiat Oncol Biol Phys. 2011;79(4):963-4.

22. Pezner RD, Tan MC, Clancy SL, Chen YJ, Joseph T, Vora NL. Radiation therapy for breast cancer patients who undergo oncoplastic surgery: localization of the tumor bed for the local boost. Am J Clin Oncol. 2013; 36(6):535-9.

23. Schaverien MV, Stallard S, Dodwell D, Doughty JC. Use of boost radiotherapy in oncoplastic breast-conserving surgery - a systematic review. Eur J Surg Oncol. 2013;39(11):1179-85

24. Offersen BV, Boersma LJ, Kirkove C, Hol S, Aznar MC, Biete Sola A, et al. ESTRO consensus guideline on target volume delineation for elective radiation therapy of early stage breast cancer. Radiother Oncol. 2015;114(1):3-10.

25. Alço G, Igdem S, Okkan S, Dincer M, Sarsenov D, Ilgun AS, et al. Replacement of the tumor bed following oncoplastic breast-conserving surgery with immediate latissimus dorsi mini-flap. Mol Clin Oncol. 2016; 5(4):365-371.

26. Kirova YM, Servois V, Reyal F, Peurien D, Fourquet A, Fournier-Bidoz N. Use of deformable image fusion to allow better definition of tumor bed boost volume after oncoplastic breast surgery. Surg Oncol. 2011;20(2):e123-5.

27. Shaikh T, Chen T, Khan A, Yue NJ, Kearney T, Cohler A, et al. Improvement in interobserver accuracy in delineation of the lumpectomy cavity using fiducial markers. Int J Radiat Oncol Biol Phys. 2010;78(4):1127-34.

28. Coles CE, Wilson CB, Cumming J, Benson JR, Forouhi P, Wilkinson JS, et al. Titanium clip placement to allow accurate tumour bed localisation following breast conserving surgery: audit on behalf of the IMPORT Trial Management Group. Eur J Surg Oncol. 2009; 35(6):578-82. Epub 2008 Oct 19.

29. Dzhugashvili M, Pichenot C, Dunant A, Balleyguier C, Delaloge S, Mathieu $\mathrm{MC}$, et al. Surgical clips assist in the visualization of the lumpectomy cavity in three-dimensional conformal accelerated partial-breast irradiation. Int J Radiat Oncol Biol Phys. 2010; 76(5):1320-4.

30. Coles C, Yarnold J. Localising the tumour bed in breast radiotherapy. Clin Oncol (R Coll Radiol). 2010;22(1):36-8.

31. Benda RK, Yasuda G, Sethi A, Gabram SG, Hinerman RW, Mendenhall NP. Breast boost: are we missing the target? Cancer. 2003;97(4):905-9.

32. Kirwan CC, Al Sarakbi W, Loncaster J, Chan HY, Thompson AM, Wishart GC. Tumour bed clip localisation for targeted breast radiotherapy: Compliance is proportional to trial-related research activity: Tumour bed clip Iocalisation in breast radiotherapy. Eur J Surg Oncol. 2014;40(2):158-62. Epub 2013 Dec 14.

33. Furet E, Peurien D, Fournier-Bidoz N, Servois V, Reyal F, Fourquet A, et al. Plastic surgery for breast conservation therapy: how to define the volume of the tumor bed for the boost? Eur J Surg Oncol. 2014;40(7):830-4.

34. Riina MD, Rashad R, Cohen S, Brownlee Z, Sioshansi S, Hepel J, et al. The Effectiveness of Intraoperative Clip Placement in Improving Radiation Therapy Boost Targeting After Oncoplastic Surgery. Pract Radiat Oncol. 2020;10(5):e348-e356. Epub 2019 Dec 19.
35. Thomas K, Rahimi A, Spangler A, Anderson J, Garwood D. Radiation practice patterns among United States radiation oncologists for postmastectomy breast reconstruction and oncoplastic breast reduction. Pract Radiat Oncol. 2014:4(6):466-71.

36. Tse T, Knowles S, Bélec J, Caudrelier JM, Lock M, Brackstone M, et al. Consensus statement on tumour bed localization for radiation after oncoplastic breast surgery. Curr Oncol. 2020;27(3):e326-e331.

37. de Freitas TB, Lopes de Barros Lima KM, de Andrade Carvalho H, de Azevedo Marques $\mathrm{P}$, et al. What a difference a clip makes! Analysis of boost volume definition in radiation therapy for conservative breast surgery. Eur $\mathrm{J}$ Surg Oncol. 2018;44(9):1312-1317.

38. Kirby AN, Jena R, Harris EJ, Evans PM, Crowley C, Gregory DL, et al. Tumour bed delineation for partial breast/breast boost radiotherapy: what is the optimal number of implanted markers? Radiother Oncol. 2013;106(2):231-5.

39. Vrieling C, van Werkhoven E, Maingon P, Poortmans P, Weltens C, Fourquet A, et al. Prognostic Factors for Local Control in Breast Cancer After Longterm Follow-up in the EORTC Boost vs No Boost Trial: A Randomized Clinical Trial. JAMA Oncol. 2017; 3(1):42-48.

40. Maguire PD, Adams A, Nichols MA. Oncoplastic surgery and radiation therapy for breast conservation: early outcomes. Am J Clin Oncol. 2015;38(4):353-7.

41. Arya R, Shakir A, Schultz O, Jutzy J. Late Toxicity and Cosmesis in Women Receiving Hypofractionated Radiotherapy after Breast-Conserving Therapy and Oncoplastic Reconstruction. International Journal of Radiation Oncology Biology Physics. 2019;105(1):E50-E51

42. Borm KJ, Schönknecht C, Nestler A, Oechsner M, Waschulzik B, Combs SE, et al. Outcomes of immediate oncoplastic surgery and adjuvant radiotherapy in breast cancer patients. BMC Cancer. 2019; 19(1):907.

43. Yang TJ, Tao R, Elkhuizen PH, van Vliet-Vroegindeweij C, Li G, Powell SN. Tumor bed delineation for external beam accelerated partial breast irradiation: a systematic review. Radiother Oncol. 2013;108(2):181-9.

44. Sung S, Lee JH, Lee JH, Kim SH, Kwak YK, Lee SW, et al. Displacement of Surgical Clips during Postoperative Radiotherapy in Breast Cancer Patients Who Received Breast-Conserving Surgery. J Breast Cancer. 2016;19(4): 417-422.

45. Bartelink $\mathrm{H}$, Bourgier $\mathrm{C}$, Elkhuizen P. Has partial breast irradiation by IORT or brachytherapy been prematurely introduced into the clinic? Radiother Oncol. 2012;104(2):139-42.

46. Garreffa E, Hughes-Davies L, Coles CE, Russell S, Lightowlers SV, Agrawal A. Definition of Tumor Bed Boost in Oncoplastic Breast Surgery: An Understanding and Approach. Clin Breast Cancer. 2020;20(4):e510-e515.

47. Shah C, Al-Hilli Z, Schwarz G. Oncoplastic Surgery in Breast Cancer: Don't Forget the Boost! Ann Surg Oncol. 2018;25(9):2509-2511.

48. Curigliano G, Burstein HJ, Winer EP, Gnant M, Dubsky P, Loibl S, et al. De-escalating and escalating treatments for early-stage breast cancer: the St. Gallen International Expert Consensus Conference on the Primary Therapy of Early Breast Cancer 2017. Ann Oncol. 2017;28(8):1700-1712. Erratum in: Ann Oncol. 2018 Oct 1;29(10):2153. Erratum in: Ann Oncol. 2019 Jan 9;: Erratum in: Ann Oncol. $2019 \mathrm{Jul} ; 30(7): 1181$.

49. Abi Jaoude J, Kayali M, de Azambuja E, Makki M, Tamim H, Tfayli A, et al. De-intensifying Radiation Therapy in HER-2 Positive Breast Cancer: To Boost or Not to Boost? Int J Radiat Oncol Biol Phys. 2020;108(4):1040-1046. 